\title{
The effects of acquisition on the growth of new technology- based firms: Do different types of acquirers matter?
}

\author{
Jing Xiao
}

Accepted: 23 March 2015/Published online: 4 April 2015

(C) The Author(s) 2015. This article is published with open access at Springerlink.com

\begin{abstract}
The growth of new technology-based firms (NTBFs) is usually restricted by their limited ownership and management structures. This paper explores whether acquisition, particularly that by multinational enterprises (MNEs), promotes the growth of NTBFs. Based on Swedish micro-level longitudinal data, this study further distinguishes between Swedish MNEs and foreign MNEs as acquirers and disentangles their different acquisition effects on the growth of NTBFs. Based on a large sample of Swedish NTBFs entering from 1997 to 2002 and being followed until 2009, this paper uses fixedeffects model combined with inverse-probability-oftreatment weights to account for endogeneity of acquisition arising from both time-invariant and time-varying heterogeneity across firms. The findings show that acquisition by Swedish MNEs significantly improves the growth of NTBFs, but only when it comes to the growth in employees. In contrast, acquisition by both foreign MNEs and Swedish domestic enterprises is not found to have any significant effects on the growth in either employees or sales of NTBFs.
\end{abstract}

J. Xiao $(\bowtie)$

CIRCLE (Centre for Innovation, Research and

Competence in the Learning Economy), Lund University,

Box 118, 22100 Lund, Sweden

e-mail: jing.xiao@circle.lu.se
Keywords Acquisition - New technology-based firms (NTBFs) · Firm growth · Multinational enterprises (MNEs) $\cdot$ Inverse-probability-of-treatment weights (IPTW) - Selection and treatment effects

JEL Classifications $\quad \mathrm{F} 23 \cdot \mathrm{G} 34 \cdot \mathrm{L} 21 \cdot \mathrm{L} 26$

\section{Introduction}

Over the recent decades, the economic slowdown of the main developed economies in Europe has directed both academic and political concerns toward entrepreneurship in general and new technology-based firms (NTBFs) in particular, with respect to their potential impact on employment growth, technology transfer, and industry renewal (Licht and Nerlinger 1998; Almus and Nerlinger 1999; Rickne and Jacobsson 1999). However, the direct growth effects of NTBFs on employment and wealth in European countries have been lower than expected not only owing to a relatively small number of NTBFs (Storey and Tether 1998) but also because most NTBFs are found to be low growth oriented (Autio 1994). One explanation is that the growth of NTBFs may be restricted by their ownership and management structures (Bonardo et al. 2010). If this argument holds, ownership changes, such as mergers and acquisitions (M\&As), may be a solution to release the growth constraint faced by NTBFs. 
The main purpose of this paper is to examine whether acquisition promotes growth of NTBFs. More specifically, this paper explores whether acquisition by multinational enterprises (MNEs) is more likely than that by domestic enterprises to promote the growth of NTBFs, given that MNEs are widely recognized as having not only high levels of ownership advantages and management skills but also international networks and linkages of knowledge, so their resources may better complement those of local NTBFs. However, compared to domestic acquirers, foreign MNEs may suffer from "liability of foreignness" (Zaheer 1995), which is likely to negatively influence the growth of NTBFs acquired by foreign MNEs. In this context, this study further distinguishes between domestic MNEs and foreign MNEs as acquirers and disentangles their different acquisition effects on the growth of NTBFs. In addition, when studying the effect of acquisition on the growth of firms, a methodological challenge is to account for the possible endogeneity of acquisition. If we observe that acquired firms have higher growth than their non-acquired counterparts, is the higher growth due to acquisition per se-acquired firms benefit from resources and capabilities transferred from acquiring firms - or to a selection effect-firms with higher growth performance or prospects are more likely to be acquired? In other words, is the higher growth of acquired firms due to the treatment effect of acquisition or a selection effect? This paper addresses this issue as well by distinguishing the selection effect ${ }^{1}$ from the treatment effect.

The relationship between acquisition and growth of NTBFs is neglected in the current literature on both entrepreneurship and M\&As. Studies on NTBFs emphasize either the supply side of NTBFs, e.g., founders' characteristics or factors related to their creation, or the determinants of post-entry performance of NTBFs (see Storey and Tether 1998, for a review). On the other hand, the M\&As literature still centers on large publicly traded firms (see, e.g.,

\footnotetext{
$\overline{1}$ This study concerns mainly two types of selection effects of acquisition: One refers to the bias that acquirers select firms with high-growth performance or prospects. The other one refers to the bias that firms with high-growth performance or prospects self-select for acquisition. See Sect. 2.1 for further discussion.
}

Veugelers 2006), usually from the perspective of acquiring firms, e.g., acquirers' motives or their postacquisition performance, but rarely focuses on what acquisition could bring to acquired firms. To the author's knowledge, no previous study has specifically distinguished acquisition effects by different types of acquirers on the growth of NTBFs. This study not only fills this research gap but is also policy relevant. Previous studies show that Europe has a relatively less-developed sector of venture capital than the USA (Bottazzi and Da Rin 2002; Revest and Sapio 2012), which is usually claimed as one main reason that it lacks a large number of high-growth NTBFs (Bertoni et al. 2011). If acquisition is found to boost the growth of NTBFs, acquisition by large established firms could function as an alternative to the venture capital market and foster innovative activities and entrepreneurship. This may have especially important implications for the economic dynamism of some European countries with a relative weak sector of venture capital.

Few empirical studies have explicitly examined the relationship between acquisition and growth of NTBFs. Granstrand and Sjölander (1990) find a positive effect of acquisition on the growth of NTBFs in their analysis based on survey data on about 100 Swedish NTBFs operating during 1945-1988. They suggest that the transfer of technological and managerial resources from acquiring firms contributes to higher post-acquisition growth for NTBFs. But they do not find a selection effect by which NTBFs exhibit higher pre-acquisition growth than non-acquired firms. Based on the same data but with more variables associated with growth, Lindholm (1996) also finds a positive effect of acquisition on the growth of NTBFs, but she finds the selection effect as well, given the higher growth of acquired NTBFs relative to nonacquired NTBFs before acquisition. Lindholm (1996) argues that the post-acquisition growth of NTBFs is promoted by the realization of technological synergies, which crucially depends on the motives of acquisition partners. One limitation of the two abovementioned studies is that their findings are difficult to generalize in a broader context owing to their relatively small number of observations. Moreover, the two studies are silent on whether different types of acquirers affect the post-acquisition growth of NTBFs differently.

This study employs data derived from the entire population of NTBFs in Sweden entering from 1997 to 
2002 in high-technology manufacturing and knowledge-intensive business services (KIBS) sectors. We construct a longitudinal dataset by following firms from entry until 2009 (if they have not exited) to discern their post-acquisition annual growth rates in terms of employees and sales. The data allow us to divide acquirers into foreign MNEs, Swedish MNEs, and Swedish domestic enterprises. Therefore, we can distinguish different acquisition effects by different acquirers on the growth of NTBFs. We compare the growth of acquired NTBFs and their non-acquired counterparts before acquisition to determine the existence of a selection effect. In terms of treatment effect, we exploit the longitudinal nature of data by combining fixed-effects model with the method of inverse-probability-of-treatment weights (IPTW) to account for endogeneity of acquisition arising from both time-invariant and time-varying heterogeneity across firms.

The findings show that both selection and treatment effects exist in the relationship between acquisition and the growth of NTBFs. The pre-acquisition growth rates of both employees and sales are higher for acquired NTBFs, especially for firms acquired by MNEs, than for non-acquired firms. In terms of the treatment effect, only acquisition by Swedish MNEs significantly improves the growth in employees for NTBFs. By contrast, acquisition by either foreign MNEs or domestic enterprises is not found to have any significant effects on growth in either employees or sales for NTBFs. The rest of this paper is organized as follows: In Sect. 2, we review the literature and propose the hypotheses; in Sect. 3, we introduce the data, sample, variables, and descriptive statistics; in Sect. 4, we explain methods and results; and in Sect. 5, we discuss the results and conclude the paper.

\section{Literature review and hypotheses}

\subsection{The selection effect}

Previous research has shown that the growth of NTBFs is restricted for at least two reasons. First, NTBFs are often initiated by entrepreneurs who possess a strong technological background but usually lack sufficient management competencies or even a strong desire to grow their companies (Autio 1994;
Bonardo et al. 2010). Second, successful commercialization of new products and services not only hinges on good innovation but also requires support from complementary assets and capabilities (Teece 1986), which are usually in the hands of established firms. In this context, a hypothesis of division of labor suggests that acquisition by established firms may provide entrepreneurs of NTBFs an exit opportunity where they can thereby focus on their expertise (Bonardo et al. 2010). Moreover, a hypothesis of "David-Goliath" symbiosis (Baumol 2002) suggests that positive synergies can be realized in the innovation process through the market of corporate control, where large firms use their complementary assets and capabilities to extend and develop innovation introduced by small firms. However, acquisitions suffer from the problem of information asymmetries (Lichtenberg et al. 1987), which are especially severe when targets are small, young, and private firms and/or when the value of a target resides mainly in high-tech intangible assets (Shen and Reuer 2005). In this vein, acquirers have to depend on some observed indicators for due diligence, such as firm growth, to evaluate the value of a potential target firm. On the other side, it is reasonable to assume that fast-growing NTBFs or those facing growth opportunities more urgently need external support in terms of resources and management capabilities than slow-growing NTBFs or those without growth prospects. Thus, the former are more likely to self-select for acquisition. Hence, the first hypothesis is proposed as follows:

H1 Acquired NTBFs exhibit higher pre-acquisition growth than non-acquired NTBFs.

The literature on international economics reveals that MNEs are characterized as being more productive, being more $R \& D$ and knowledge intensive, focusing more on technologically cutting-edge products, getting more involved in product differentiation strategies, having more intangible assets, and so on (see, e.g., Markusen 1998). These advantages allow them to cover transaction costs arising from the process of internationalization, particularly when they are engaged in FDI (foreign direct investment; see, e.g., Markusen 1998; Helpman et al. 2004). In this vein, MNEs should have even stronger ownership advantages and management capabilities than purely domestic enterprises. With their superior knowledge and managerial capabilities, MNEs may have a better 
ability to select target firms. Furthermore, entrepreneurs in high-growth NTBFs are enticed to sell their companies to MNEs to obtain a higher reward or initiate an internationalization strategy (Norbäck and Persson 2014), given MNEs' strengths in resources, management, and international networks. The second hypothesis is then proposed as follows:

H2 NTBFs acquired by MNEs exhibit higher preacquisition growth than NTBFs acquired by domestic enterprises.

\subsection{The treatment effect}

\subsubsection{The positive effect}

Acquiring firms can transfer both resources and management capabilities to acquired firms after acquisition. For example, the imperfection of external capital markets is recognized to be the most important factor hindering the growth of small and young firms (Brito and Mello 1995). By contrast, an internal capital market is thought to be more effective for acquired firms for at least three reasons. First, corporate headquarters have more precise "company-specific information" about their subsidiaries than outside investors do (Hubbard and Palia 1998). Second, internal capital markets can eliminate extra transaction costs associated with external financing (Matsusaka and Nanda 2002). Third, corporate headquarters are more flexible in shifting resources to the most efficient subsidiaries within corporations to maximize expected profits (Stein 1997). The "winner-picking" strategy (Stein 1997) suggests that acquired firms with high prospects not only benefit from regular investments from headquarters but are also able to obtain extra financing that could have been distributed to other competing subsidiaries. These advantages relax the constraints in financial resources faced by NTBFs and are thought to promote their post-acquisition growth. In addition, according to the matching theory of ownership change (Lichtenberg et al. 1987), acquisition provides a new matching opportunity for firms that suffer from incompatibility between their potentials and the management competencies to correct their efficiency lapses. NTBFs are usually initiated by a group of experts in a specific field who lack skills in management (Bonardo et al. 2010). Established firms could replace inefficient management teams of NTBFs through acquisition in the market of corporate control and then boost the growth of NTBFs.

Moreover, the resource-based view (RBV) treats firms as a bundle of resources, including tangible resources (such as financial and physical assets) and intangible resources (such as know-how, patents, and organizational routines) (Wernerfelt 1984; Barney 1991). The competitive advantage of a firm rests in a specific configuration of its existing resources. Drawing on RBV, firm growth is described as a process of discovering new productive opportunities (Penrose 2009). New productive opportunities can emerge when managers find new ways of using slack resources or combining existing resources (Lockett et al. 2011). In line with this argument, acquisition may increase the scope of economies and decrease path dependence arising from the process of resource accumulation (Lockett et al. 2011), giving firms better chances of discovering new productive opportunities and thus higher growth opportunities.

\subsubsection{The negative effect}

But at the same time, acquisition may also exert a negative effect on the growth of NTBFs. For example, the RBV also suggests that the process of discovering new productive opportunities always generates associated adjustment costs (Lockett et al. 2011). These costs come from firm growth but have a negative effect on the future growth of the firm. In the context of acquisition, the main adjustment costs arise from the post-integration process. Previous studies reveal that unsuccessful post-acquisition integration is the main reason that most M\&As fail (see, e.g., Shrivastava 1986). The issues arising from post-acquisition integration, such as disruption in organizational routines, agency problems, increased management control, and conflicts in culture and bureaucracy (Hitt et al. 1990, 1996; Ahuja and Katila 2001), are detrimental to growth of NTBFs after acquisition.

\subsection{Multinational enterprises}

Acquisition may have both positive and negative effects on acquired NTBFs, but these effects may 
offset each other in the post-acquisition process. In this case, it would be difficult to draw an ex ante hypothesis about the treatment effects of acquisition on the growth of NTBFs based on theories and previous studies. A better solution may be to distinguish treatment effects of different acquirers. First, we could assume that acquisition by Swedish MNEs and Swedish domestic enterprises impose a similarly negative effect on NTBFs in the postacquisition process. However, as discussed above, MNEs should have stronger ownership advantages and management capabilities than purely domestic enterprises. NTBFs acquired by MNEs are thought to have better access to complementary assets and capabilities than their counterparts acquired by Swedish domestic enterprises. Moreover, MNEs have international networks and linkages, which enable NTBFs to access global stocks of knowledge and resources (Andersson and Lööf 2012) that may be more complementary to their knowledge base. In this case, compared to firms acquired by Swedish domestic enterprises, firms acquired by Swedish MNEs improve their chances of discovering new productive opportunities after acquisition. The third hypothesis is proposed as follows:

H3 Compared to Swedish domestic enterprises, Swedish MNEs are more likely to promote the postacquisition growth of NTBFs.

Second, we could assume that acquisition by foreign MNEs and Swedish MNEs has a similarly positive effect on NTBFs in the post-acquisition process. But foreign MNEs may face more transaction costs abroad due to economic, institutional, and cultural differences (Zaheer 1995; Barkema et al. 1996; Shimizu et al. 2004). Due to the liability of foreignness, foreign MNEs are assumed to have a stronger negative effect than Swedish MNEs on the post-acquisition growth of NTBFs. For example, the liability of foreignness may lead to more errors in the pre-acquisition process when acquirers select target firms. Moreover, the liability of foreignness may also create more challenges in the post-acquisition integration process. The fourth hypothesis is then proposed as follows:

H4 Compared to Swedish MNEs, foreign MNEs are less likely to promote the post-acquisition growth of NTBFs.

\section{Data, sample, variables, and descriptive statistics}

\subsection{Data and sample}

The dataset ${ }^{2}$ used in this paper is constructed by merging several databases from Statistics Sweden (SCB), including data on matched employer-employee, business group, business statistics, ${ }^{3}$ population register, and Swedish inventors. ${ }^{4}$ There are two steps to define and identify NTBFs. First, we define entrepreneurial firms as new, small, independent start-ups that exploit entrepreneurial opportunities (Ejermo and Xiao 2014). Following Eriksson and Kuhn (2006) and Andersson and Klepper (2013), we employ dynamic information from matched employer-employee data and trace the flows of employees among workplaces over time to identify new small independent start-ups (with 1-10 initial employees). Second, NTBFs are defined as entrepreneurial firms entering in high-technology manufacturing or knowledge-intensive business services (KIBS) sectors. In this study, "high technology" includes high-tech and medium-high-tech manufacturing sectors. The definition of these sectors is based on the industry classification of OECD (Hatzichronoglou 1997; Eurostat 2011). KIBS includes "post and telecommunications" (NACE ${ }^{5}$ code 64$)$, "computer and related activities" (NACE code 72), "research and development" (NACE code 73), and "other business activities" (NACE code $74^{6}$ ), according to the definition by Miles (2005). ${ }^{7}$

The paper considers two more aspects when constructing the sample of NTBFs. First, the sample

\footnotetext{
$\overline{2 \text { More details }}$ on the construction of the original dataset can be found in Ejermo and Xiao (2014). In this paper, we update the original datast by adding business statistics and extending the follow-up year to 2009 .

${ }^{3}$ Business statistics have been deflated by the consumer price index (CPI) derived from SCB. Base year $=1980$.

${ }^{4}$ Details of inventor data can be found in Jung and Ejermo (2014).

5 NACE Version 1.1.

${ }^{6}$ Some subsectors under NACE division 74 are excluded, according to the definition by Miles (2005).

${ }^{7}$ In his study, Miles (2005) mentioned that KIBS may also exist in other sectors, such as telecommunications, but did not explicitly include "Post and telecommunications" (NACE code 64 ) in his definition of major KIBS sectors. This paper, however, includes "Post and telecommunications" in KIBS sectors.
} 
selects firms entering from 1997 to 2002 . The reason is that business statistics are available for the whole population of firms only since 1997 . Second, about $26 \%$ of NTBFs are dropped because the value of their ratio of cash flow to sales is below the 1st or above the 99th percentile, or the value of their labor productivity is missing. The final sample contains 43,688 unique firms entering from 1997 to 2002 and follows them from 1998 until 2009 (if they have not exited), for a total of 122,049 observations.

\subsection{Variables}

We measure firm growth as relative change in firm size between two consecutive years. The annual growth rate is calculated by taking log-differences of size (Coad 2007); see Eq. (1). ${ }^{8}$ Firm size is indicated by employees or sales, which are the two most widely used growth indicators in previous studies on firm growth (Delmar 1997; Delmar et al. 2003).

growth $_{i t}=\ln \left(X_{i t}\right)-\ln \left(X_{i t-1}\right)$

The independent variables consist of a large set of founder-specific, firm-specific, and industry-specific characteristics, which will be discussed separately as follows.

\subsubsection{Acquisition}

Acquisition is the main variable of interest. An acquisition is identified when a NTBF joins a business group. This means that the business group obtains a controlling position in the NTBF by possessing over $50 \%$ of the voting rights. Acquisition is further divided into acquisition by foreign MNEs, Swedish MNEs, and Swedish domestic enterprises.

\subsubsection{Growth in the previous year}

There is evidence that the annual growth rates of small firms are subject to a negative serial correlation (Coad 2007). In this study, we account for the serial

\footnotetext{
${ }^{8}$ We calculate the annual growth rates by measuring a relative change. Literature on firm growth notes that the relative measure favors growth of small firms compared to large firms (Delmar 1997). We do not think this is a problem in our analysis. First, our sample contains only small firms. Second, we control for the size of firms in the previous year in our analysis.
}

correlation of annual growth rates by including the growth rates in the previous year as a control variable.

\subsubsection{Age and size}

Substantive literature reveals that firm size and age are negatively related to the growth of new firms (see, e.g., Jovanovic 1982; Evans 1987). We control for firm size measured by the logarithm of the number of employees and age by including dummies for each age.

\subsubsection{Human capital and technical capital}

Human capital and technical capital are important founder-specific characteristics and found to have a positive impact on the growth of NTBFs (Storey and Tether 1998; Almus and Nerlinger 1999). This study uses the share of employees with tertiary education or above to indicate human capital and the share of scientists and engineers and the presence of inventor(s) in the initial employees to indicate the technical capital of a firm (Ejermo and Xiao 2014).

\subsubsection{Firm types}

Founders' ex ante experience, particularly working experience, is found to be closely related to post-entry growth of new firms (Colombo and Grilli 2005; Santarelli and Vivarelli 2007). For example, spin-offs are considered to have higher growth than other types of new firms as spin-offs can inherit knowledge and routines from their parent companies (Nelson and Winter 1982; Klepper and Sleeper 2005; Eriksson and Kuhn 2006; Andersson and Klepper 2013). By contrast, the founders' unemployment status in the preentry stage is found to have a negative impact on postentry growth as unemployed individuals are likely to start a new firm as a way of escaping unemployment (Santarelli and Vivarelli 2007). This study controls for founders' working experience by including variables of firm types. Following Andersson and Klepper (2013), NTBFs are divided into five types: pulled spinoffs, pushed spin-offs, other new firms, unemployment firms, and self-employment firms.

\subsubsection{Internal financial resources}

As discussed above, because of imperfections in external financial markets, internal finances may be 
the main financial resource of new firms (Carpenter and Petersen 2002) and are thus expected to have a positive impact on the growth of NTBFs. Following Andersson and Lööf (2012), the ratio of cash flow to sales is used as a proxy for internal financial resources and is controlled for in this study.

\subsubsection{Labor productivity}

We control for labor productivity, which serves as one quality indicator of new firms. Labor productivity is measured by the logarithm of the ratio of value added to the number of employees.

\subsubsection{Industry controls}

Industry dummies (defined as two-digit NACE code) are included to accommodate industry-specific effects on firm growth.

\subsubsection{Location controls}

This study controls for regional effects by including regional dummies to indicate whether firms are located in the three main metropolitan regions (Stockholm, Gothenburg, and Malmo) or in the remaining regions in Sweden.

Among the variables discussed above, the presence of inventor(s) and firm types are time-invariant variables and are measured according to their initial values at entry year of NTBFs. The rest are timevarying variables and measured based on their current values annually.

\subsection{Descriptive statistics}

Table 1 describes the main variables and reports mean values for all firms, firms acquired by foreign MNEs, Swedish MNEs, and Swedish domestic enterprises, and non-acquired firms. ${ }^{9}$ In the total sample, about $3.6 \%$ of NTBFs had been acquired by business groups by 2009 . Among others, about $0.4 \%$ of NTBFs were acquired by foreign MNEs and $0.2 \%$ by Swedish MNEs. Although acquired firms represent only a small share of all firms in the sample, they display distinctive characteristics not shared by non-acquired firms.

\footnotetext{
${ }^{9}$ Firms are defined as acquired firms if they are acquired within the observation period, otherwise as non-acquired firms.
}

Table 1 also shows $t$ tests on the equality of means by comparing firms acquired by different types of acquirers and non-acquired firms. Compared to nonacquired firms, acquired firms, particularly firms acquired by MNEs, are significantly larger and more productive; they have significantly higher growth rates of employees, sales, and technical capital but fewer internal financial resources on average. In terms of firm types, acquired firms are significantly more likely to be spin-offs and other new firms and are less likely to be self-employment firms compared to non-acquired firms. However, the statistics in Table 1 confound information both before and after acquisition. That means any differences between non-acquired firms and acquired firms may contain both selection and treatment effects.

Figure 1 displays the histograms of the growth rates of acquired and non-acquired firms over the period 1998-2009. ${ }^{10,11}$ It is noteworthy that growth in employees and sales are both highly skewed, especially in terms of growth in employees. The share of firm-year observations with zero growth in employees is about $82 \%$ for all firms, $84 \%$ for non-acquired firms, and $56 \%$ for acquired firms.

Table 2 shows the correlation matrix of current growth rates and growth rates in the previous year. The current growth rates of employees and sales show significantly negative correlations with their respective growth rates in the previous year. This is consistent with the findings of Coad (2007) that small firms have a negative serial correlation in terms of annual growth rates.

\section{Methods and results}

The benchmark regression models used in this paper are displayed in Eqs. (2a), (2b), and (2c), which are termed as model (a), (b), and (c), respectively.

growth $_{i t}=\alpha+\beta_{1} \mathrm{Ac}_{i t}+\gamma C_{i t-1}+\delta_{t}+\varepsilon_{i, t}$

\footnotetext{
${ }^{10}$ The growth rates are missing at entry year, and thus, the growth rates are observed from 1998 to 2009.

11 Please note that the scales of both the $\mathrm{x}$-axis and $\mathrm{y}$-axis are different between the upper and lower graphs in Fig. 1.
} 


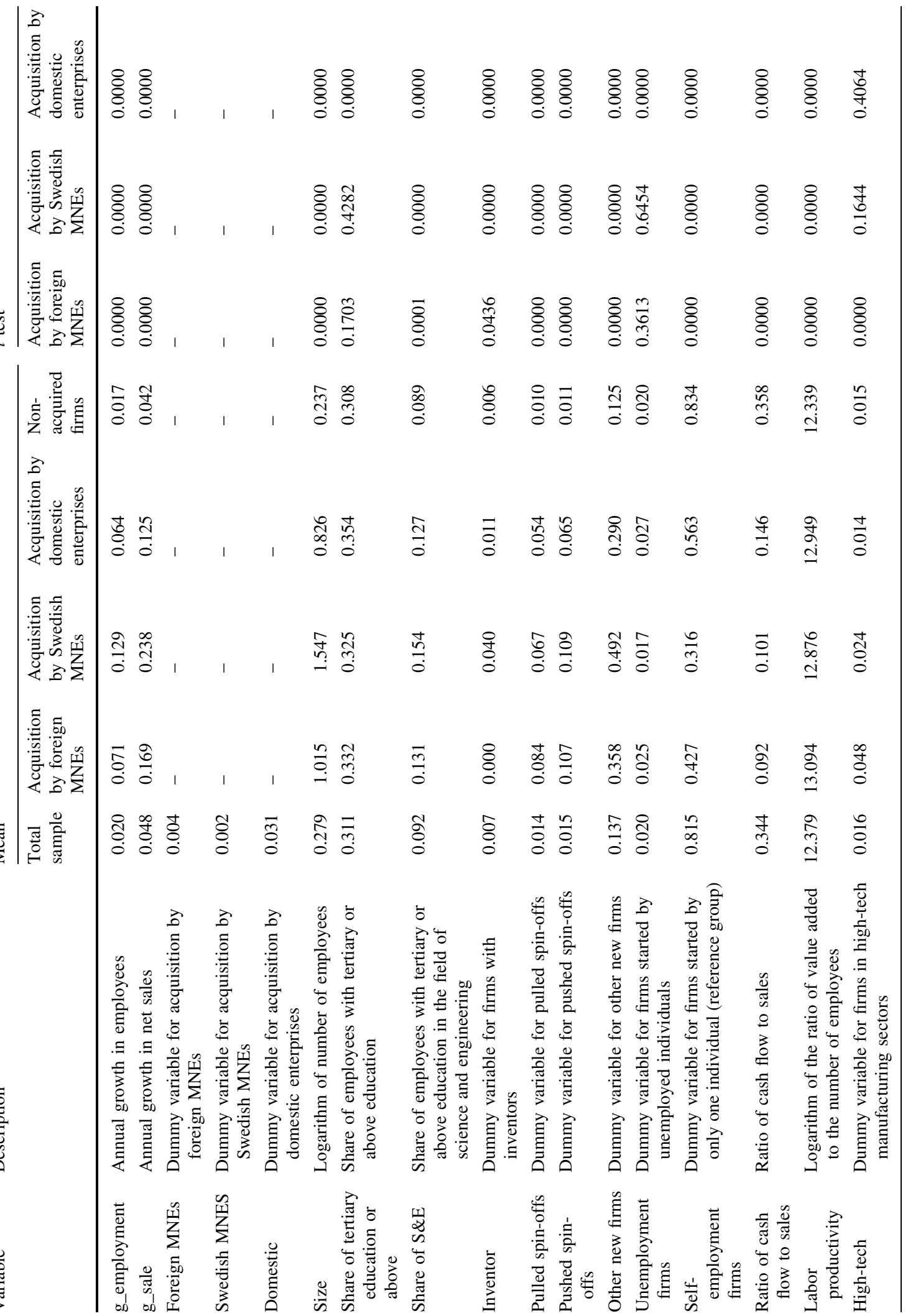




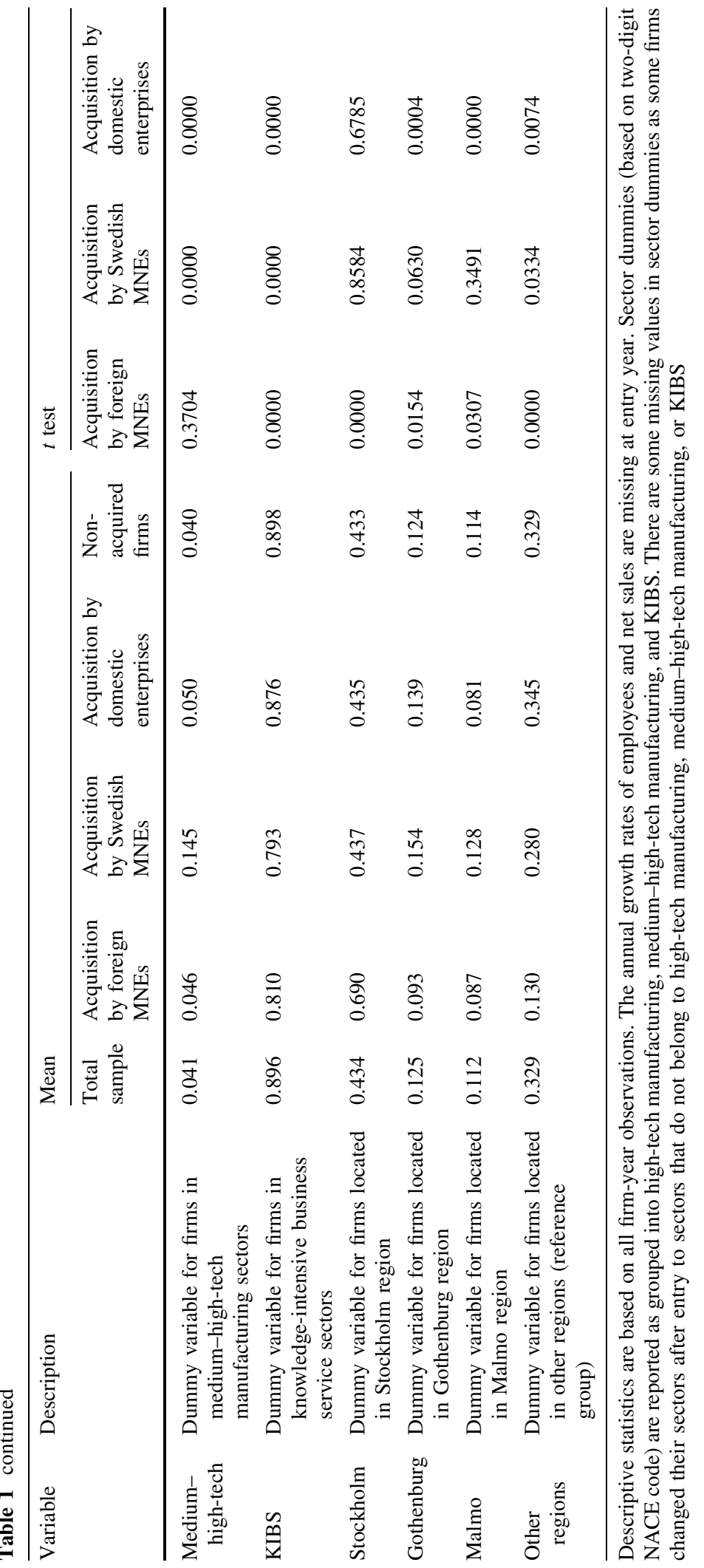


Fig. 1 Histogram of the annual growth rates of employees and sales
Table 2 Correlations of current growth and the growth in the previous year

$* * * p<0.01$. L1 refers to a one-year lag
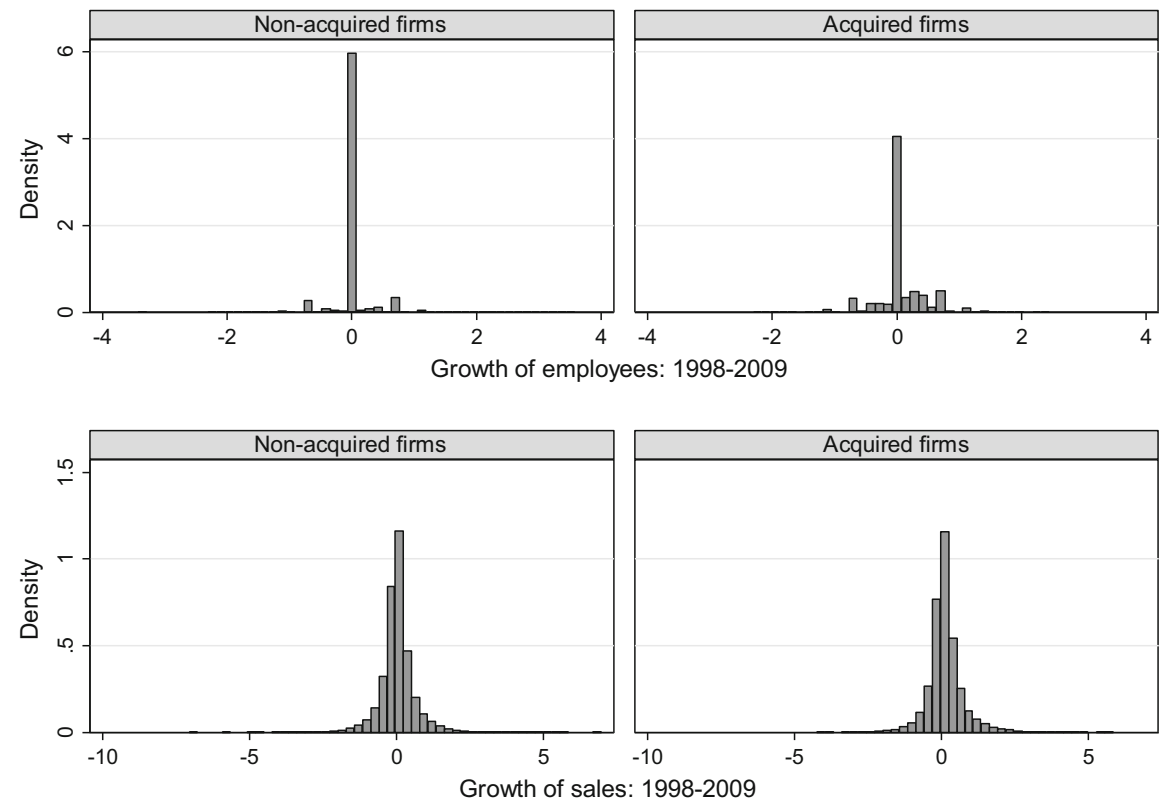

\begin{tabular}{lclcc}
\hline Variables & g_employment & g_employment_L1 & g_sales & g_sales_L1 \\
\hline g_employment & 1 & & & \\
g_employment_L1 & $-0.2542 * * *$ & 1 & 1 & \\
g_sales & $0.1409 * * *$ & $0.0578 * * *$ & $-0.2295 * * *$ & 1 \\
g_sales_L1 & $0.0283 * * *$ & $0.1279 * * *$ & & \\
\hline
\end{tabular}

growth $_{i t}=\alpha+\beta_{1}$ For $_{i t}+\beta_{2}$ Swe $_{i t}+\beta_{3}$ Dom $_{i t}$ $+\gamma C_{i t-1}+\delta_{t}+\varepsilon_{i, t}$

growth $_{i t}=\alpha+\beta_{1}$ For $_{i t}+\beta_{2}$ Swe $_{i t}+\gamma C_{i t-1}+\delta_{t}+\varepsilon_{i, t}$

where $i$ refers to firm $i$; $t$ refers to year $t$; $\mathrm{Ac}_{i t}$ is a dummy variable indicating the status of being acquired; For $_{i t}, \mathrm{Swe}_{i t}$, and $\mathrm{Dom}_{i t}$ are dummy variables indicating the status of being acquired by foreign MNEs, Swedish MNEs, and Swedish domestic enterprises, respectively; $C_{i t-1}$ is a vector of control variables with one-year lag; ${ }^{12} \delta_{t}$ refers to year dummies. In model (a) and (b), we include all firms, both acquired and non-acquired, and take non-acquired firms as the reference group. In model (c), we include only acquired firms and take firms acquired by

\footnotetext{
12 The reason that we use control variables with one-year lag is to avoid for the possible problem of simultaneity.
}

Swedish domestic enterprises as the reference group. Thus, model (a) captures the growth differences of acquired firms relative to non-acquired firms. Model (b) captures the growth differences of firms by different acquirers, respectively, relative to nonacquired firms. Model (c) captures the growth differences of firms acquired by two types of MNEs, respectively, relative to firms acquired by Swedish domestic enterprises.

\subsection{The selection effect}

The main aim of this paper is to examine the treatment effect of acquisition on the growth of NTBFs. One methodological challenge is that acquisition may be endogenous to firm growth, which means firm growth may predict acquisition (the selection effect). In order to detect whether a selection effect exists in the relationship between acquisition and firm growth, we first compare the growth differences based on the observations before acquisition. ${ }^{13}$ In this section, the 
dummy variables that indicate the status of being acquired or being acquired by different acquirers in model (a), (b), and (c) are adjusted to: $\mathrm{Ac}_{i t}$ (firms that will be acquired in the future); For ${ }_{i t}$ (firms that will be acquired by foreign MNEs in the future); $\mathrm{Swe}_{i t}$ (firms that will be acquired by Swedish MNEs in the future), and $\operatorname{Dom}_{i t}$ (firms that will be acquired by Swedish domestic enterprises in the future). The models are estimated by pooled OLS, and results are reported in Table 3.

From Table 3, it is noteworthy that acquired firms have significantly higher growth rates than non-acquired firms in both employees and sales before acquisition. Moreover, compared to non-acquired firms, the preacquisition growth for firms acquired by foreign MNEs is about 11 and $12 \%$ higher in employees and sales, respectively; about 22 and $23 \%$ higher for firms acquired by Swedish MNEs; and about 9 and $15 \%$ higher for firms acquired by Swedish domestic enterprises. However, compared to firms acquired by Swedish domestic enterprises, the higher pre-acquisition growth in both employees and sales is significant only for firms acquired by Swedish MNEs-about $9 \%$ higher in employees and $8 \%$ higher in sales.

The results in Table 3 support H1: Acquired firms exhibit significantly higher pre-acquisition growth than non-acquired firms. However, $\mathrm{H} 2$ is only partially supported. Compared to firms acquired by Swedish domestic enterprises, firms acquired by Swedish MNEs are found to have a significantly higher preacquisition growth in both employees and sales, while firms acquired by foreign MNEs are not. One possible explanation is that foreign MNEs may have a different motive than Swedish MNEs for acquisition in Sweden. Compared to Swedish MNEs, foreign MNEs may be more likely to use acquisition as an entry mode or a channel for learning in a foreign market (Shimizu et al. 2004). Moreover, foreign MNEs may be in an inferior position than Swedish MNEs to acquire firms with top performance in growth due to a liability of foreignness.

\footnotetext{
13 Alternatively, a logit model can be employed to explore whether growth rates in the previous year predict an event of acquisition in the current year. But in our sample, over $30 \%$ of acquired firms are acquired in the first year after entry, which means their growth rates in the year before they are acquired are missing. Thus, the logit model is not chosen here.
}

\subsection{The treatment effect}

The results in the last section show that the selection effect does exist in the relationship between acquisition and growth of NTBFs. Previous studies usually employ the propensity score matching or inverse propensity score weighting to account for the endogeneity of acquisition (see, e.g., Bandick and Görg 2010). The rationale of propensity score matching is to construct an artificial control group based on the observed characteristics across firms before treatment to make the treatment between treatment and control group as random as possible. However, we do not think propensity score matching is an appropriate method in the current context. First, propensity score matching does not control for unobserved firm-level heterogeneity unless it can be combined with the difference-in-difference approach (Arnold and Javorcik 2009). Second, observed heterogeneity may change over time and with the status of acquisition. However, the propensity score matching controls only for cross-sectional heterogeneity based on observed characteristics before treatment. The rationale of using the inverse propensity score weighting is to use the inverse propensity scores as weights to account for the endogeneity problem. However, the inverse propensity score weighting is not chosen in this study. The reasons are that compared to IPTW (inverse-probabilityof-treatment weights), this method may suffer from substantial residual confounding and is difficult to generalize to the situation with time-dependent exposures (Robins et al. 2000, p. 559).

In this study, we employ the fixed-effects approach to account for the selection effect arising from timeinvariant firm-level heterogeneity across firms, both observed and unobserved. Moreover, the selection effect may also arise from time-varying heterogeneity across firms. For example, the propensity of acquisition may vary with time-varying variables. Moreover, acquisition in the previous period may impact covariates in the current period, which in turn affect growth in the future. In this case, the standard fixed-effects approach still gives a biased estimate of the treatment effect without considering time-varying confounders. In this context, we follow Azoulay et al. (2009) in using a new estimator, IPTW (inverse-probability-oftreatment weights), developed originally in biostatistics (Robins et al. 2000), to account for time-varying confounders. Following Fewell et al. (2004), IPTW in this paper are constructed as shown in Eq. (3). 
Table 3 The selection effect: pooled OLS regression results based on observations before acquisition

\begin{tabular}{|c|c|c|c|c|c|c|}
\hline \multirow[t]{2}{*}{ Variables } & \multicolumn{2}{|l|}{ (a) } & \multicolumn{2}{|l|}{ (b) } & \multicolumn{2}{|l|}{ (c) } \\
\hline & g_employment & g_sale & g_employment & g_sale & g_employment & g_sale \\
\hline Acquisition & $\begin{array}{l}0.0943 * * * \\
(0.00831)\end{array}$ & $\begin{array}{c}0.152 * * * \\
(0.00963)\end{array}$ & & & & \\
\hline Foreign MNEs & & & $\begin{array}{l}0.112 * * * \\
(0.0327)\end{array}$ & $\begin{array}{l}0.124 * * * \\
(0.0356)\end{array}$ & $\begin{array}{c}0.0103 \\
(0.0307)\end{array}$ & $\begin{array}{r}-0.0447 \\
(0.0383)\end{array}$ \\
\hline Swedish MNEs & & & $\begin{array}{l}0.223 * * * \\
(0.0350)\end{array}$ & $\begin{array}{l}0.225 * * * \\
(0.0380)\end{array}$ & $\begin{array}{l}0.0912 * * * \\
(0.0341)\end{array}$ & $\begin{array}{c}0.0832 * \\
(0.0435)\end{array}$ \\
\hline Domestic & & & $\begin{array}{l}0.0857 * * * \\
(0.00861)\end{array}$ & $\begin{array}{l}0.149 * * * \\
(0.0101)\end{array}$ & $\begin{array}{l}- \\
-\end{array}$ & $\begin{array}{l}- \\
-\end{array}$ \\
\hline Control variables & Yes & Yes & Yes & Yes & Yes & Yes \\
\hline Constant & $\begin{array}{c}-0.337 * * * \\
(0.0144)\end{array}$ & $\begin{array}{l}1.604 * * * \\
(0.0407)\end{array}$ & $\begin{array}{c}-0.337 * * * \\
(0.0144)\end{array}$ & $\begin{array}{l}1.604 * * * \\
(0.0407)\end{array}$ & $\begin{array}{r}-0.0238 \\
(0.150)\end{array}$ & $\begin{array}{l}2.386 * * * \\
(0.327)\end{array}$ \\
\hline Obs & 90,918 & 90,918 & 90,918 & 90,918 & 2468 & 2468 \\
\hline R-squared & 0.104 & 0.108 & 0.104 & 0.108 & 0.082 & 0.162 \\
\hline
\end{tabular}

Robust standard errors in parentheses; $* * * p<0.01$; ** $p<0.05 ; * p<0.1$. Estimated coefficients of control variables and year dummies are not reported

$w_{i t}=\prod_{j=t 0}^{t} \frac{1}{\operatorname{Prob}\left(A_{i j} \mid \bar{A}_{i, j-1}, \bar{X}_{i j}\right)}$

where $i$ refers to firm i; $t$ refers to year $t ; t 0$ refers to entry year. Each factor in the denominator of Eq. (3) estimates the firm's probability of receiving observed treatment of acquisition for each firm-year observation at year $j$, conditional on its previous history of acquisition ${ }^{14}$ and covariates (Azoulay et al. 2009). The denominator then calculates the firm's conditional probability of receiving observed treatment of acquisition for each firm-year observation up to year $\mathrm{t}$, given its previous history of acquisition and covariates (Fewell et al. 2004). By inversing the estimated probabilities, observations with higher probabilities of acquisition receive lower weights, while observations with lower probabilities of acquisition receive higher weights. The aim of the IPTW estimator is to make a treatment as random as possible by accounting for time-varying confounders. In order to correct for the skewed distribution and high variance of $w_{i t}$, we also follow Fewell et al. (2004) in employing a stabilized version of IPTW; see Eq. (4).

\footnotetext{
${ }^{14}$ In this study, we focus only on the first acquisition of NTBFs and drop observations once acquired firms are observed to be divested from their acquiring firms.
}

$\mathrm{sw}_{i t}=\prod_{j=t 0}^{t} \frac{\operatorname{Prob}\left(A_{i j} \mid \bar{A}_{i, j-1}, \bar{X}_{i t 0}\right)}{\operatorname{Prob}\left(A_{i j} \mid \bar{A}_{i, j-1}, \bar{X}_{i t}\right)}$

The numerator calculates the firm's conditional probability of receiving observed treatment of acquisition for each firm-year observation up to year $t$, given its previous history of acquisition and the values of covariates at entry year (Fewell et al. 2004).

Another advantage of the IPTW estimator is that it may also account for a survival bias that arises from time-varying heterogeneity across firms. The conventional growth model is often criticized for its potential survival bias because we can observe only surviving firms in the data instead of the whole population of firms. The growth patterns of surviving firms could be systematically different from firms that do not survive. Moreover, survival bias could be even worse in a sample of small and new firms, which usually experience a high exit rate. Thus, following Fewell et al. (2004), we use IPTW to control for survival bias ${ }^{15}$ also. The weight that will account for this bias is derived through a similar way as the one described in Eqs. (3) and (4), where exit is substituted for acquisition as the treatment. The final IPTW used in the

\footnotetext{
${ }^{15}$ In the study of Fewell et al. (2004), they use the term "censoring" to address the situation when observations cannot be observed in the data.
} 
regression are the product of the weights that account for the selection effect of acquisition and the weights that account for survival bias. We include the final IPTW for each firm-year observation in the fixedeffects regression models to control for time-varying heterogeneity across firms. ${ }^{16}$

Table 4 reports the results of model (a), (b), and (c) estimated by the fixed-effects method. As fixedeffects models control for constant firm-level heterogeneity, time-invariant control variables, such as the presence of inventor(s) and firm types, are not included in the estimation. In the first column, acquisition is found to significantly improve the growth in employees for NTBFs. However, in the second column, the effect of acquisition on the growth in sales is not statistically significant. In the third column, both Swedish MNEs and domestic enterprises are found to have a significantly positive effect on the growth in employees for NTBFs. However, in the fourth column, none of the three types of acquirers are found to have a statistically significant effect on growth in sales for NTBFs. When we compare the growth differences between acquired firms, we find in the fifth column that only the coefficient of Swedish MNEs is significant. This implies that Swedish MNEs are more likely to promote the growth of NTBFs in employees compared to Swedish domestic enterprises. However, no coefficients in the sixth column are statistically significant.

We employ IPTW-weighted fixed-effects method to re-estimate model (a), (b), and (c) to further control for time-varying confounders. The results are reported in Table 5. In the first and second columns, we find that the coefficients of acquisition become insignificant after further controlling for time-varying confounders. In the third column, Swedish MNEs are still found to significantly improve the growth in employees for NTBFs. But the coefficient is smaller than that in Table 4, where time-varying confounders are not controlled for. In the fourth column, none of the three types of acquirers are found to have a statistically significant effect on growth in sales for NTBFs. When we compare the growth differences between acquired firms, the results in the fifth column show that the coefficient of Swedish MNEs is still statistically

\footnotetext{
$\overline{16}$ We use "areg" command in STATA 13 to fit the fixed effects models. We weight each firm-year observation by including the command "[pw = final IPTW]" in the regressions.
}

significant although lower than that in Table 4. In the sixth column, no coefficients are statistically significant.

From the results reported in Tables 4 and 5, we find that at least in terms of growth in employees, Swedish MNEs are more likely to promote the post-acquisition growth of NTBFs, compared to Swedish domestic enterprises. This therefore supports $\mathrm{H} 3$ in terms of growth in employees. In order to test $\mathrm{H} 4$, we need to use one-sided $t$ tests to explore whether the coefficients of Swedish MNEs are significantly higher than those of foreign MNEs based on the estimation in the third and fifth columns in Table 5. The results are reported in the notes in Table 5, showing that $\mathrm{H} 4$ is also supported in terms of growth of employees. Compared to the findings of Lindholm (1996), this study also finds both selection and treatment effects in the relationship between acquisition and the growth of NTBFs. But in terms of the treatment effect of acquisition, we find that only acquisition by Swedish MNEs significantly improves the growth in employees for NTBFs.

\subsection{Robustness check}

Recall that about $26 \%$ of firms from the whole population of NTBFs were dropped from the data sample because of missing or unreliable values in two variables-ratio of cash flow to sales and labor productivity. In order to check whether the results are sensitive to the dropping of those firms, we employ the IPTW-weighted fixed-effects method to re-estimate model (b) and (c) for the whole population of NTBFs. Due to the missing or unreliable values in the variables mentioned above, we can test the effect of acquisition only on growth of employees, and the two variables-ratio of cash flow to sales and labor productivity-are not included in the control variables. The results reported in Table 6 generally exhibit a similar pattern to that in Table 5. Swedish MNEs are still found to significantly improve the post-acquisition growth in employees of NTBFs.

\section{Discussion and conclusion}

The findings in this paper show that both selection and treatment effects exist in the relationship between acquisition and growth of NTBFs. In terms of the 
Table 4 The treatment effect: fixed-effects regression results

\begin{tabular}{|c|c|c|c|c|c|c|}
\hline \multirow[t]{2}{*}{ Variables } & \multicolumn{2}{|l|}{ (a) } & \multicolumn{2}{|l|}{ (b) } & \multicolumn{2}{|l|}{ (c) } \\
\hline & g_employment & g_sale & g_employment & g_sale & g_employment & g_sale \\
\hline Acquisition & $\begin{array}{l}0.0537 * * * \\
(0.0140)\end{array}$ & $\begin{array}{c}0.00782 \\
(0.0203)\end{array}$ & & & & \\
\hline Foreign MNEs & & & $\begin{array}{c}0.00305 \\
(0.0798)\end{array}$ & $\begin{array}{c}0.215 \\
(0.141)\end{array}$ & $\begin{array}{r}-0.0362 \\
(0.0701)\end{array}$ & $\begin{array}{c}0.203 \\
(0.149)\end{array}$ \\
\hline Swedish MNEs & & & $\begin{array}{l}0.212 * * * \\
(0.0452)\end{array}$ & $\begin{array}{c}0.0660 \\
(0.0631)\end{array}$ & $\begin{array}{l}0.136 * * * \\
(0.0399)\end{array}$ & $\begin{array}{c}0.0448 \\
(0.0627)\end{array}$ \\
\hline Domestic & & & $\begin{array}{l}0.0464 * * * \\
(0.0147)\end{array}$ & $\begin{array}{r}-0.00566 \\
(0.0208)\end{array}$ & - & - \\
\hline Control variables & Yes & Yes & Yes & Yes & Yes & Yes \\
\hline Constant & $\begin{array}{c}-0.307 * * * \\
(0.0497)\end{array}$ & $\begin{array}{l}6.086^{* * * *} \\
(0.151)\end{array}$ & $\begin{array}{c}-0.306 * * * \\
(0.0497)\end{array}$ & $\begin{array}{l}6.088 * * * \\
(0.151)\end{array}$ & $\begin{array}{r}-0.271 \\
(0.213)\end{array}$ & $\begin{array}{l}5.822 * * * \\
(0.505)\end{array}$ \\
\hline Obs & 94,877 & 94,877 & 94,877 & 94,877 & 6427 & 6427 \\
\hline R-squared & 0.459 & 0.431 & 0.459 & 0.432 & 0.466 & 0.426 \\
\hline
\end{tabular}

Robust standard errors in parentheses; $* * * p<0.01$; ** $p<0.05 ; * p<0.1$. Estimated coefficients of control variables and year dummies are not reported. Based on observations both before and after acquisition

Table 5 The treatment effect: IPTW-weighted fixed-effects regression results

\begin{tabular}{|c|c|c|c|c|c|c|}
\hline \multirow[t]{2}{*}{ Variables } & \multicolumn{2}{|l|}{ (a) } & \multicolumn{2}{|l|}{ (b) } & \multicolumn{2}{|l|}{ (c) } \\
\hline & g_employment & g_sale & g_employment & g_sale & g_employment & g_sale \\
\hline Acquisition & $\begin{array}{c}0.0205 \\
(0.0158)\end{array}$ & $\begin{array}{r}-0.0249 \\
(0.0273)\end{array}$ & & & & \\
\hline Foreign MNEs & & & $\begin{array}{r}-0.0683 \\
(0.0870)\end{array}$ & $\begin{array}{c}0.0673 \\
(0.0781)\end{array}$ & $\begin{array}{r}-0.0918 \\
(0.0808)\end{array}$ & $\begin{array}{c}0.0275 \\
(0.0861)\end{array}$ \\
\hline Swedish MNEs & & & $\begin{array}{l}0.149 * * * \\
(0.0387)\end{array}$ & $\begin{array}{r}-0.0659 \\
(0.105)\end{array}$ & $\begin{array}{l}0.0953 * * \\
(0.0378)\end{array}$ & $\begin{array}{c}-0.0880 \\
(0.117)\end{array}$ \\
\hline Domestic & & & $\begin{array}{c}0.0177 \\
(0.0167)\end{array}$ & $\begin{array}{r}-0.0270 \\
(0.0292)\end{array}$ & - & - \\
\hline Control variables & Yes & Yes & Yes & Yes & Yes & Yes \\
\hline Constant & $\begin{array}{c}-0.157 * * * \\
(0.0581)\end{array}$ & $\begin{array}{l}5.594 * * * \\
(0.296)\end{array}$ & $\begin{array}{c}-0.156 * * * \\
(0.0581)\end{array}$ & $\begin{array}{l}5.594 * * * \\
(0.296)\end{array}$ & $\begin{array}{r}-0.111 \\
(0.198)\end{array}$ & $\begin{array}{l}6.418 * * * \\
(0.686)\end{array}$ \\
\hline Obs & 93,552 & 93,552 & 93,552 & 93,552 & 6417 & 6417 \\
\hline R-squared & 0.466 & 0.468 & 0.466 & 0.468 & 0.494 & 0.507 \\
\hline
\end{tabular}

Robust standard errors in parentheses; *** $p<0.01$; ** $p<0.05$; $* p<0.1$. Estimated coefficients of control variables and year dummies are not reported. Based on observations both before and after acquisition. (1) One-sided $t$ tests on coefficients after estimation in the third column: H0: Swedish MNEs $\leq$ Foreign MNEs: $p=0.0000$; (2) One-sided $t$ tests on coefficients after estimation in the fifth column: H0: Swedish MNEs $\leq$ Foreign MNEs: $p=0.0000$

selection effect, we find that, compared to nonacquired firms, the pre-acquisition growth rates of both employees and sales are higher for acquired NTBFs, especially for firms acquired by MNEs. In terms of the treatment effect, we only find that acquisition by Swedish MNEs significantly improves the growth in employees for NTBFs. By contrast, neither acquisition by foreign MNEs nor acquisition by 
Table 6 The treatment effect: IPTW-weighted fixed-effects regression results - a robustness check based on the whole population of NTBFs

\begin{tabular}{lll}
\hline Variables & $(\mathrm{b})$ & (c) \\
& g_employment & g_employment \\
\hline Foreign MNEs & 0.0246 & -0.0131 \\
& $(0.0593)$ & $(0.0596)$ \\
Swedish MNEs & $0.125^{* * *}$ & $0.0839^{* *}$ \\
& $(0.0360)$ & $(0.0372)$ \\
Domestic & 0.00191 & - \\
& $(0.0128)$ & - \\
Control variables & Yes & Yes \\
Constant & $0.177 * * *$ & -0.0948 \\
& $(0.0444)$ & $(0.322)$ \\
Obs & 134,306 & 9738 \\
R-squared & 0.461 & 0.502 \\
\hline
\end{tabular}

Robust standard errors in parentheses; $* * * p<0.01$; $* * p<0.05 ; * p<0.1$. Estimated coefficients of control variables and year dummies are not reported. Based on observations both before and after acquisition. The variables of ratio of cash flow to sales and labor productivity are not included in the control variables. (1) One-sided $t$ tests on coefficients after estimation in the third column: H0: Swedish MNEs $\leq$ Foreign MNEs: $p=0.0025$; (2) One-sided $t$ tests on coefficients after estimation in the fifth column: H0: Swedish MNEs $\leq$ Foreign MNEs: $p=0.0047$

Swedish domestic enterprises is found to exert a significant treatment effect on growth in either employees or sales for NTBFs.

Our findings generally support the arguments in the literature that domestic MNEs seem to be in a superior position to the other two types of acquirers in terms of both selection and treatment effects of acquisition. Compared to purely domestic enterprises, domestic MNEs have a higher level of ownership advantages and management capabilities and good access to a global stock of knowledge and resources. Compared to foreign MNEs, domestic MNEs do not suffer from the liability of foreignness and are less affected by information asymmetries in the market of corporate control. These advantages give domestic MNEs the capability to select or attract top performance firms in growth to be acquired. On the other hand, the advantages also allow domestic MNEs to exhibit a positive effect on the post-acquisition growth in employees for NTBFs.

However, we did not find that domestic MNEs have a significantly positive effect on the growth of sales. One assumption is that in our case, the effect of acquisition on the growth in sales may take longer time to unfold than that on the growth in employees. This assumption is contrary to the conventional idea that the change in employees is usually lagged than the change in financial indicators (Delmar 1997). However, in the current context, acquired firms can make a quick decision to hire new personnel for future strategic plans with the support of parent companies. By contrast, the realization of the growth in sales may be longer as responses from the market may take some time. However, further analyses are needed to verify this assumption.

The findings of this paper are both research and policy relevant. First, this study bridges two fragmented areas of literature-entrepreneurship and M\&As. Second, Europe is believed to be lagging behind the USA in terms of economic dynamism owing to a small number of high-growth NTBFs (Storey and Tether 1998). One main reason for this lagging behind in entrepreneurial activities is claimed to be a relatively less-developed venture capital sector (Bottazzi and Da Rin 2002; Bertoni et al. 2011; Revest and Sapio 2012). In this context, our findings indicate that acquisition by domestic MNEs can be an effective way to release the growth constraint faced by NTBFs and may function as an alternative to the venture capital market and foster entrepreneurship. Third, this study finds that acquisition is endogenous to firm growth, which obscures the treatment effect of acquisition on growth of NTBFs. The endogeneity of acquisition is from not only time-invariant but also time-varying heterogeneity across firms. IPTW provides a new approach to control for possible timevarying confounders.

Although this study does not find any significant treatment effects of foreign acquisition on the growth of NTBFs, we cannot rule out that acquisition by foreign acquirers and their Swedish counterpart is subject to different motives. For example, foreign MNEs may be more likely to use acquisition as an entry mode or a channel for learning in a foreign market (Shimizu et al. 2004). Moreover, acquisition by foreign MNEs is also likely to be motivated by improved access to local resources, such as intangible assets or firm-specific tacit knowledge, which are difficult to trade individually in traditional factor markets (Lockett et al. 2011). In this scenario, foreign acquirers may rely on acquisition to acquire resources or knowledge but may not intend to further promote 
the growth of NTBFs after acquisition. However, due to data limitations, we cannot identify and distinguish different motives by different types of acquirers. This is one limitation of this study.

Moreover, it should be noted that the IPTW estimator controls for time-varying heterogeneity based on observed characteristics. If the selection problem also arises from time-varying but unobserved heterogeneity, the estimate from the IPTW estimator is still biased even after controlling for individual fixed effects. One important assumption when one uses IPTW to make a causal inference is that there is no unobserved heterogeneity in the model (Fewell et al. 2004). Although we have accounted for a large set of control variables in our analysis to minimize time-varying unobserved heterogeneity, we are still conservative about making any causal inferences regarding the relationship between acquisition and growth of NTBFs.

Acknowledgments An earlier version of this paper was presented at the 15th International Conference of the International Joseph Alois Schumpeter Society (ISS) in July 2014 in Jena, Germany. I am grateful to Martin Andersson at CIRCLE for his generous and overall help for this paper, particularly in defining entry and exit of new firms and mergers and acquisitions. I also would like to express my thanks to Olof Ejermo, Torben Schubert, Alex Coad, Katrin Hussinger and two anonymous referees for their constructive comments on earlier versions of this paper. Niclas Lavesson at CIRCLE is appreciated for his generous help for the location data.

Open Access This article is distributed under the terms of the Creative Commons Attribution 4.0 International License (http:// creativecommons.org/licenses/by/4.0/), which permits unrestricted use, distribution, and reproduction in any medium, provided you give appropriate credit to the original author(s) and the source, provide a link to the Creative Commons license, and indicate if changes were made.

\section{References}

Ahuja, G., \& Katila, R. (2001). Technological acquisitions and the innovation performance of acquiring firms: A longitudinal study. Strategic Management Journal, 22(3), 197-220. doi:10.1002/smj.157.

Almus, M., \& Nerlinger, E. A. (1999). Growth of new technologybased firms: Which factors matter? Small Business Economics, 13(2), 141-154. doi:10.1023/a:1008138709724.

Andersson, M., \& Klepper, S. (2013). Characteristics and performance of new firms and spinoffs in Sweden. Industrial and Corporate Change, 22(1), 245-280. doi:10.1093/icc/ dts046.
Andersson, M., \& Lööf, H. (2012). Small business innovation: Firm level evidence from Sweden. Journal of Technology Transfer, 37(5), 732-754. doi:10.1007/s10961-011-9216-9.

Arnold, J. M., \& Javorcik, B. S. (2009). Gifted kids or pushy parents? Foreign direct investment and plant productivity in Indonesia. Journal of International Economics, 79(1), 42-53. doi:10.1016/j.jinteco.2009.05.004.

Autio, E. (1994). New, technology-based firms as agents of R\&D and innovation: an empirical study. Technovation, 14(4), 259-273. doi:10.1016/0166-4972(94)90010-8.

Azoulay, P., Ding, W., \& Stuart, T. (2009). The impact of academic patenting on the rate, quality and direction of (public) research output. Journal of Industrial Economics, 57(4), 637-676. doi:10.1111/j.1467-6451.2009.00395.x.

Bandick, R., \& Görg, H. (2010). Foreign acquisition, plant survival, and employment growth. Canadian Journal of Economics, 43(2), 547-573. doi:10.1111/j.1540-5982. 2010.01583.x.

Barkema, H. G., Bell, J. H. J., \& Pennings, J. M. (1996). Foreign entry cultural barriers and learning. Strategic Management Journal, 17(2), 151-166. doi:10.1002/(sici)10970266(199602)17:2<151:aid-smj799>3.0.co;2-z.

Barney, J. (1991). Firm resources and sustained competitive advantage. Journal of Management, 17(1), 99-120. doi:10. 1177/014920639101700108.

Baumol, W. J. (2002). Entrepreneurship, innovation and growth: The David-Goliath symbiosis. Journal of Entrepreneurial Finance, 7(2), 1-10. http://digitalcommons. pepperdine.edu/jef/vol7/iss $2 / 2$

Bertoni, F., Colombo, M. G., \& Grilli, L. (2011). Venture capital financing and the growth of high-tech start-ups: Disentangling treatment from selection effects. Research Policy, 40(7), 1028-1043. doi:10.1016/j.respol.2011.03.008.

Bonardo, D., Paleari, S., \& Vismara, S. (2010). The M\&A dynamics of European science-based entrepreneurial firms. Journal of Technology Transfer, 35(1), 141-180. doi:10. 1007/s10961-009-9109-3.

Bottazzi, L., \& Da Rin, M. (2002). Venture capital in Europe and the financing of innovative companies. Economic Policy, 17(34), 229-270. doi:10.1111/1468-0327.00088.

Brito, P., \& Mello, A. S. (1995). Financial constraints and firm post-entry performance. International Journal of Industrial Organization, 13(4), 543-565. doi:10.1016/0167-7187 (95)00504-8.

Carpenter, R. E., \& Petersen, B. C. (2002). Is the growth of small firms constrained by internal finance? Review of Economics and Statistics, 84(2), 298-309. doi:10.1162/ 003465302317411541.

Coad, A. (2007). A closer look at serial growth rate correlation. Review of Industrial Organization, 31(1), 69-82. doi:10. 1007/s11151-007-9135-y.

Colombo, M. G., \& Grilli, L. (2005). Founders' human capital and the growth of new technology-based firms: A competence-based view. Research Policy, 34(6), 795-816. doi:10.1016/j.respol.2005.03.010.

Delmar, F. (1997). Measuring growth: Methodological considerations and empirical results. In R. Donckels \& A. Miettinen (Eds.), Entrepreneurship and SME research: On its way to the next millennium (pp. 199-216). Aldershot: Ashgate. 
Delmar, F., Davidsson, P., \& Gartner, W. B. (2003). Arriving at the high-growth firm. Journal of Business Venturing, 18(2), 189-216. doi:10.1016/S0883-9026(02)00080-0.

Ejermo, O., \& Xiao, J. (2014). Entrepreneurship and survival over the business cycle: How do new technology-based firms differ? Small Business Economics, 43(2), 411-426. doi:10.1007/s11187-014-9543-y.

Eriksson, T., \& Kuhn, J. M. (2006). Firm spin-offs in Denmark 1981-2000-Patterns of entry and exit. International Journal of Industrial Organization, 24(5), 1021-1040. doi:10.1016/j.ijindorg.2005.11.008.

Eurostat. (2011). High technology and knowledge-intensive sectors [PDF document]. European Commission. http:// epp.eurostat.ec.europa.eu/cache/ITY_SDDS/Annexes/ hrst_st_esms_an9.pdf

Evans, D. S. (1987). The relationship between firm growth, size, and age: Estimates for 100 manufacturing industries. Journal of Industrial Economics, 35(4), 567-581. doi:10. 2307/2098588.

Fewell, Z., Hernán, M. A., Wolfe, F., Tilling, K., Choi, H., \& Sterne, J. A. C. (2004). Controlling for time-dependent confounding using marginal structural models. Stata Journal, 4(4), 402-420. http://www.stata-journal.com/ article.html? article $=$ st0075

Granstrand, O., \& Sjölander, S. (1990). The acquisition of technology and small firms by large firms. Journal of Economic Behavior \& Organization, 13(3), 367-386. doi:10.1016/0167-2681(90)90006-y.

Hatzichronoglou, T. (1997). Revision of the high-technology sector and product classification (OECD Science, Technology and Industry working papers, 1997/02). Paris, France: OECD Publishing. doi:10.1787/134337307632

Helpman, E., Melitz, M., \& Yeaple, S. (2004). Export versus FDI with heterogeneous firms. American Economic Review, 94, 300-316. doi:10.1257/000282804322970814.

Hitt, M. A., Hoskisson, R. E., \& Ireland, R. D. (1990). Mergers and acquisitions and managerial commitment to innovation in m-form firms. Strategic Management Journal, 11, Special Issue: Corporate Entrepreneurship. (Summer, 1990), 29-47, doi:10.2307/2486668

Hitt, M. A., Hoskisson, R. E., Johnson, R. A., \& Moesel, D. D. (1996). The market for corporate control and firm innovation. Academy of Management Journal, 39(5), 1084-1119. http://www.jstor.org/stable/256993

Hubbard, R. G., \& Palia, D. (1998). A re-examination of the conglomerate merger wave in the 1960s: An internal capital markets view (working paper no. 6539). Cambridge, MA: National Bureau of Economic Research (NBER). http://www.nber.org/papers/w6539

Jovanovic, B. (1982). Selection and the evolution of industry. Econometrica, 50(3), 649-670. http://www.jstor.org/ stable/1912606

Jung, T., \& Ejermo, O. (2014). Demographic patterns and trends in patenting: Gender, age, and education of inventors. Technological Forecasting and Social Change, 86(2014), 110-124. doi:10.1016/j.techfore.2013.08.023.

Klepper, S., \& Sleeper, S. (2005). Entry by spinoffs. Management Science, 51(8), 1291-1306. doi:10.1287/mnsc.1050. 0411.

Licht, G., \& Nerlinger, E. (1998). New technology-based firms in Germany: A survey of the recent evidence. Research
Policy, 26(9), 1005-1022. doi:10.1016/s0048-7333(97) 00056-5.

Lichtenberg, F. R., Siegel, D., Jorgenson, D., \& Mansfield, E. (1987). Productivity and changes in ownership of manufacturing plants. Brookings Papers on Economic Activity, 1987(3), 643-683. doi:10.2307/2534451.

Lindholm, А. (1996). Acquisition and growth of technologybased firms (working paper no. 47). Cambridge, UK: University of Cambridge, ESRC Centre for Business Research.

Lockett, A., Wiklund, J., Davidsson, P., \& Girma, S. (2011). Organic and acquisitive growth: Re-examining, testing and extending penrose's growth theory. Journal of Management Studies, 48(1), 48-74. doi:10.1111/j.1467-6486. 2009.00879.x.

Markusen, J. R. (1998). Multinational firms, location and trade. World Economy, 21(6), 733-756. doi:10.1111/1467-9701. 00161.

Matsusaka, J. G., \& Nanda, V. (2002). Internal capital markets and corporate refocusing. Journal of Financial Intermediation, 11(2), 176-211. doi:10.1006/jfin.2001.0333.

Miles, I. (2005). Knowledge intensive business services: Prospects and policies. Foresight, 7(6), 39-63. doi:10.1108/ 14636680510630939.

Nelson, R. R., \& Winter, S. G. (1982). An evolutionary theory of economic change. Cambridge: The Belknap Press of Harvard University Press.

Norbäck, P.-J., \& Persson, L. (2014). Born to be global and the globalisation process. World Economy, 37(5), 672-689. doi:10.1111/twec.12132.

Penrose, E. T. (2009). The theory of the growth of the firm (4th ed.). Oxford: Oxford University Press.

Revest, V., \& Sapio, A. (2012). Financing technology-based small firms in Europe: What do we know? Small Business Economics, 39(1), 179-205. doi:10.1007/s11187-0109291-6.

Rickne, A., \& Jacobsson, S. (1999). New technology-based firms in Sweden-A study of their direct impact on industrial renewal. Economics of Innovation and New Technology, 8(3), 197-223. doi:10.1080/1043859990 0000009.

Robins, J. M., Hernán, M. A., \& Brumback, B. (2000). Marginal structural models and causal inference in epidemiology. Epidemiology, 11(5), 550-560. http://www.jstor.org/ stable/3703997

Santarelli, E., \& Vivarelli, M. (2007). Entrepreneurship and the process of firms' entry, survival and growth. Industrial and Corporate Change, 16(3), 455-488. doi:10.1093/icc/ $\mathrm{dtm} 010$.

Shen, J.-C., \& Reuer, J. (2005). Adverse selection in acquisitions of small manufacturing firms: A comparison of private and public targets. Small Business Economics, 24(4), 393-407. doi:10.1007/s11187-005-5332-y.

Shimizu, K., Hitt, M. A., Vaidyanath, D., \& Pisano, V. (2004). Theoretical foundations of cross-border mergers and acquisitions: A review of current research and recommendations for the future. Journal of International Management, 10(3), 307-353. doi:10.1016/j.intman.2004. 05.005 .

Shrivastava, P. (1986). Postmerger integration. Journal of Business Strategy, 7(1), 65-76. doi:10.1108/eb039143. 
Stein, J. C. (1997). Internal capital markets and the competition for corporate resources. Journal of Finance, 52(1), 111-133. http://www.jstor.org/stable/2329558

Storey, D. J., \& Tether, B. S. (1998). New technology-based firms in the European Union: An introduction. Research Policy, 26(9), 933-946. doi:10.1016/s0048-7333(97)00052-8.

Teece, D. J. (1986). Profiting from technological innovation: Implications for integration, collaboration, licensing and public policy. Research Policy, 15(6), 285-305. doi:10. 1016/0048-7333(86)90027-2.
Veugelers, R. (2006). Literature review on M\&A and R\&D. In B. Cassiman \& M. G. Colombo (Eds.), Merger and acquisitions: The innovation impact (pp. 79-118). Cheltenham: Elgar.

Wernerfelt, B. (1984). A resource-based view of the firm. Strategic Management Journal, 5(2), 171-180. doi:10. 1002/smj.4250050207.

Zaheer, S. (1995). Overcoming the liability of foreignness. Academy of Management Journal, 38(2), 341-363. doi:10. 2307/256683. 